Maciej Michalski*

\title{
Współczesny apokryf biblijny jako forma latencji
}

DOI: http://dx.doi.org/10.12775/LC.2019.033

Streszczenie: W artykule zaproponowano potraktowanie wybranych współczesnych apokryfów biblijnych należących do dwudziestowiecznej literatury polskiej jako form latencji opisanej przez Hansa Ulricha Gumbrechta. Spośród trzech przedstawionych przez niemieckiego badacza konfiguracji toposów latencji dwa wydają się szczególnie korespondować z przywoływanymi w artykule utworami: „zła wiara” oraz „wykolejenie historii”. Pierwsza konfiguracja łączy w sobie potrzebę dotarcia do prawdy z koniecznością pokonywania licznych i mnożonych celowo przeszkód utrudniających zdobycie pożądanej wiedzy. Druga z kolei opiera się na rozczarowaniu teraźniejszością, która nie spełniła pokładanych w niej nadziei, co rodzi egzystencjalny niepokój. Przykładem tej konfiguracji mogą być Ludzie Izraela czyli Skutkach bezinteresowności Leszka Kołakowskiego, gdzie autor konfrontuje opisane w Biblii obietnice Boga wobec Żydów z ich późniejszą historią. Egzemplifikacją sytuacji, w której dominuje „zła wiara” połączona z ujawnianiem „choreografii wydobywania prawdy”, może być Kieł Barabasza Gustawa Herlinga-Grudzińskiego, w którym bohater usiłuje odkryć istotną jego zdaniem dla historii Zbawienia prawdę o tytułowej relikwii. Prawda okazuje się być mocno zamaskowana, ukryta za wieloma wersjami i interpretacjami, a pisarz stosuje tu typową dla swojej prozy poetykę apokryficzną. Utwory literackie interpretowane $\mathrm{w}$ artykule zdają się być egzemplifikacją obu wspomnianych powyżej konfiguracji toposów latencji, czasem łącząc oba na raz. Tym samym można uznać, że niektóre współczesne apokryfy biblijne mogą być wyrazem latentnej kondycji naszej współczesności.

Słowa kluczowe: apokryf, Biblia, latencja, Hans Ulrich Gumbrecht, Leszek Kołakowski, Gustaw Herling-Grudziński

\footnotetext{
* Dr hab., prof. nadzwyczajny w Katedrze Teorii Literatury i Krytyki Artystycznej Instytutu Filologii Polskiej Uniwersytetu Gdańskiego. Zajmuje się związkami literatury i filozofii, metodologią badań literaturoznawczych oraz polską prozą XX wieku.

E-mail: maciej.michalski@ug.edu.pl | ORCID: 0000-0002-6397-2582.
} 


\title{
Contemporary Biblical Apocrypha as a Form of Latency
}

\begin{abstract}
The paper proposes an interpretation of selected contemporary biblical apocrypha representing the twentieth century Polish literature as forms of latency conceived by Hans Ulrich Gumbrecht. Two of three described by German researcher "configurations" of topoi of latency seem to be present in short stories analyzed in the paper: "bad faith" and "derailment of history". First configuration is a combination of a need to know the truth and necessity of overcoming numerous and intentionally multiplicated obstacles. The second one is based on being disappointed with the present times which didn't meet the expectations - raising some existential anxiety. A good example of the late one is The People of Israel, or the Consequences of Unselfishness by Leszek Kolakowski, where the author confronts God's promises with the history of Jews. Eye Tooth of the Barabbas by Gustaw Herling-Grudziński is an exemplification of "bad faith" joint with "choreography of revealing truth". In this apocryphal short story the main character tries to find, important in his perspective and crucial for the history of Redemption, truth of the title relic. The truth is deeply hidden behind many versions and interpretations as the author used his typical apocryphal poetics. Each of the texts interpreted in the article is the exemplification of one configuration of the latency topoi mentioned above, sometimes being a combination of both of them. Therefore, I consider some of contemporary biblical apocrypha an expression of a latent state of our present era.
\end{abstract}

Key words: apocrypha, Bible, latency, Hans Ulrich Gumbrecht, Leszek Kolakowski, Gustaw Herling-Grudziński

iterackie nawiązania do Biblii można potraktować jak lustro czy raczej soczewkę. Różnorodność tych odniesień, pisarskich motywacji oraz okoliczności, a także bogactwo biblijnych przekazów sprawiają, że ten obszar literatury więcej mówi o tych, którzy do Biblii nawiązują, niż o niej samej. Można z pewną przesadą uznać nawet, że z Pismem da się zrobić niemal wszystko, może być ono pretekstem do artykulacji wszelkich poglądów, artystycznych założeń czy kondycji kultury w danym momencie, w którym biblijne nawiązania się pojawiają. Szczególnie interesującym zjawiskiem na tym tle są apokryfy - z ich ambiwalencją, złamaną, problematyczną, niejako metonimiczną (anty)kanonicznością ${ }^{1}$.

Jak sądzę, można uznać, że również współczesne apokryfy biblijne mogą być wyrazem powojennej latencji - stanu, który da się opisać metaforą „pasażera na gapę”, kiedy „czujemy, że nieuchwytne i niedotykalne coś (lub ktoś) jest z nami - i że owo coś (bądź ktoś) posiada materialny wymiar, to znaczy: zajmuje przestrzeń” (Gumbrecht 2015: 44). Być może - a nie jest to zbyt zaskakująca teza - podskórny nurt trwania powojennej traumy jest odreagowywany przez szukanie oparcia w powrocie do kanonu, do stabilnych wartości i ka-

\footnotetext{
1 Szerzej o zjawisku apokryficzności w Michalski 2003 (rozdział: Strategia apokryficzna). Tu również o specyfice apokryficznego pisarstwa L. Kołakowskiego oraz G. Herlinga-Grudzińskiego, których teksty omówię w dalszej części artykułu, nie będę zatem przywoływać ustaleń z ww. książki. Nie chcąc także wchodzić w złożone rozważania dotyczące apokryficzności, szczególnie biblijnej, przyjmuję szerokie jej rozumienie jako tekstu literackiego o tematyce biblijnej (Szajnert 2000: 142-143).
} 
tegorii, jakie oferuje m.in. Biblia. Ale jednocześnie ten powrót nie jest i być nie może prostą aprobatywną reaktywacją czy wyrazem nostalgii za fundamentem, porządkiem - choć przecież tak można pojmować klasycyzujące tendencje we współczesnej literaturze. Dzisiejsze apokryfy rodzą się z przeczucia, że kanonu nie da się reaktywować wprost, zacierając czy wypierając dwudziestowieczne doświadczenia, ale jedynie w sposób złamany, problematyzujący, nieoczywisty; tym być może różnią się od apokryfów dawnych. Apokryficzna ambiwalencja w tym ujęciu byłaby wyrazem latencji, która uniemożliwia kategoryczność, myślenie mocne, esencjalne.

Współczesne apokryfy także relatywizują kanon za sprawą wprowadzenia perspektywy historycznej. Zabieg uwspółcześnienia można bowiem traktować jako wyraz nadziei na ponadczasowość kanonu (skoro da się go transponować w dwudziestowieczne realia), ale jednocześnie podanie w wątpliwość jego uniwersalności. Opis biblijnych zdarzeń i postaci za pomocą współczesnych kategorii czy realiów, szczególnie parodystyczny lub ironiczny, relatywizuje źródłowy antyczny hipotekst.

Hans Ulrich Gumbrecht w swojej pracy Po roku 1945. Latencja jako źródło wspótczesności opisuje za pomocą egzemplifikacji pochodzących z różnych obszarów kultury oraz zbiorowych i własnych doświadczeń powojenne Stimmungen stanowiące „kombinację pewnego układu posiadanej wiedzy z poczuciem, że otaczający nas świat materialny zarówno wymaga naszego uczestnictwa, jak i na nas wpływa”, a pojawiające się ,jako reakcja na latencję i jej konsekwencja” (Gumbrecht 2015: 56). Ten „ontologicznie niesamowity amalgamat we wszystkich swoich wariantach - które można nazwać toposami, podkreślając przestrzenne konotacje terminu pochodzącego z tradycji retorycznej - wytwarza nie tylko pewne pragnienia, lecz także niejednokrotnie uczucia sprzeciwu towarzyszące spełnianiu tychże pragnień” (ibid.: 56). Gumbrecht wyróżnia trzy konfiguracje tych toposów charakteryzujących powojenne Stimmung. Pierwsza „sprzęga klaustrofobiczne poczucie zamknięcia w przestrzeni, która pozostaje »bez wyjścia «, z przeciwną, ale komplementarną obsesją znajdowania się wewnątrz przestrzeni »bez wejścia «” (ibid.). W drugiej „kwestia złej wiary [...] łączy się z choreografią i regułami obowiązującymi w rytuałach wydobywania prawdy” (ibid.: 57). I w trzeciej wreszcie „twórcy i postacie literackie odkrywają, jak bardzo ich teraźniejszość różni się od przewidywań poczynionych na jej temat wtedy, gdy wciąż była przyszłością w przeszłości. [...] To skrzyżowanie toposów wiąże się z uczuciem, że długo wyczekiwana (i wysoce pożądana) przyszłość nie nadeszła, co powoduje dezorientację i niepokój egzystencjalny” (ibid.: 58). Prowadzi to do zrodzenia możliwości „innej, niehistorycystycznej $\gg$ konstrukcji czasu $\ll-$ to jest nowego $\gg$ chronotopu $\ll[\ldots]$ ".. (ibid.: 207).

Gumbrecht ukazuje to zawieszenie historycystycznej koncepcji czasu na przykładzie poematu pt. Apokryf autorstwa Jánosa Pilinszky'ego. Użyta przez węgierskiego poetę metafora „przemijania ze zmarszczką” dobrze opisuje konkretną teraźniejszość chronotopu postępu zaczynającego zwalniać i sprawiać ból: „Niema przyszłość i zmarszczka teraźniejszości współwystępują z zamarznięciem, paraliżem, ociężałością przeszłości i jej oporem przed pozostaniem $\gg \mathrm{za} \ll$ nami - tam, gdzie jej »miejsce «. [...] Między niemotą, zmarszczeniem i paraliżem czas przestaje poruszać się w przód, rozwój i przyspieszenie zastępuje zaś stagnacja” (ibid.: 256-257). Tę refleksję Gumbrecht ilustruje fragmentem poematu Pilinszky'ego: 
Bóg mnie widzi jak stoję na słońcu.

Widzi cień na kamieniu, na płocie.

Widzi cień mój bez oddechu stojący

w bezpowietrznej, stężonej drętwocie.

(Pilinszky 1999: 59)

Wprowadzenie boskiej perspektywy można uznać za poszukiwanie zewnętrznego, niezależnego, nieruchomego punktu odniesienia. Nie daje to wprawdzie pocieszenia - przeciwnie, raczej poczucie bezradności wobec kamiennej obojętności Absolutu, a nawet jego nieprzewidywalności i ślepego okrucieństwa: „Cisza nieba oderwie się naraz od ziem, które Bóg w otchłań rzuci” (Pilinszky 1999: 56). W świetle tych rozważań istotne jest pewne łączenie perspektyw świadczące, jak się wydaje, o zagubieniu, poszukiwaniu utraconego poczucia przewidywalności i stabilności. Nie dziwi zatem odwoływanie się do Biblii powiązane z łączeniem mitycznego porządku czasowego ze współczesnością, które zachodzi w części dwudziestowiecznych apokryfów, co pozwala wiązać je z opisywanym przez Gumbrechta latentnym „wykolejeniem historii”.

Takie bowiem zachwianie porządku czasowego dochodzi do głosu w apokryficznych transformacjach. Jednym z częstych zabiegów w wypadku próz nawiązujących do Biblii jest, jak pisze Maciej Nowak, uwspółcześnianie, w wypadku którego autorzy „modernizują biblijne opowieści nie z intencją przybliżenia Pisma współczesności, ale w celu »wpisania « weń swego świata idei. To ich teraźniejszość, ich »środowisko« modeluje wykorzystany biblijny materiał" (Nowak 2002: 42).

Tak dzieje się często w apokryficznych Opowieściach biblijnych Leszka Kołakowskiego. Autor konfrontuje biblijną perspektywę i realia ze świadomością dwudziestowiecznego racjonalisty-sceptyka, mającego w świeżej (latentnej?) pamięci doświadczenia totalitaryzmów. W Ludziach Izraela czyli Skutkach bezinteresowności narrator przytacza wyznanie Boga dotyczące bezinteresownego umiłowania ludu wybranego, po czym podaje je w wątpliwość:

Deklaracja była wprawdzie złożona już po wyzwoleniu z Egiptu, ale za to przed: cesarstwem rzymskim, inkwizycją hiszpańską, sprawą Dreyfusa,

Trzecią Rzeszą,

ONR-em

i kilkoma innymi okolicznościami podobnej natury.

Rozważając sprawę na trzeźwo, trudno nie zauważyć, że ta miłość zupełnie bezinteresowna i te oświadczenia o szczególnej opiece, jaką lud boży miał być otoczony przez Stwórcę, okazały się w skutkach dosyć nikłej wartości (Kołakowski 1990: 111-112).

Ten fragment dobrze ilustruje wspomnianą powyżej modernizację i wprowadzenie współczesnej perspektywy. Jednak, jak się wydaje, to nałożenie planów czasowych nie służy tylko - pretekstowo - wyłożeniu własnych racji, jest tu bowiem widoczne to, o czym pisał Gumbrecht: zawód teraźniejszością (a właściwie całą historią), która okazała się nie spełniać wyjściowych (zbudowanych przez Objawienie) oczekiwań dotyczących tego, co miałoby nadejść. Uwspółcześnienie nie musi przecież oznaczać „wykolejenia historii”. Niemniej jeśli 
taki zabieg dotyczy realiów biblijnych lub sposobu interpretowania ich sensu, motywacje i/ lub konsekwencje takiego zabiegu wydają się inne, istotniejsze. W świetle Objawienia historia - czyli to, co nastąpi po zdarzeniach opisanych na kartach Pisma Świętego - nabiera innego sensu: staje się wypełnianiem proroctw i zapowiedzi, a jednocześnie oczekiwaniem na paruzję. Dzieje ludzkości zyskują zatem szczególną wagę, a przede wszystkim mają cel i sens. Apokryficzne odwołanie do Biblii i uwspółcześnianie jej realiów może być przypomnieniem tych „wyjściowych” założeń, pokazaniem ich permanentnej aktualności. Ale nie u Kołakowskiego, który zdaje się mówić: „sprawdzam”. Podaje w wątpliwość przekaz biblijny nie tyle w celu ekspresji własnych poglądów (choć rzecz jasna dochodzi i do tego), ale aby weryfikować zasadność, trafność, a może objawiony charakter Pisma.

Nie jest jednak też tak, że w miejsce judeochrześcijańskiego sensu historii Kołakowski podstawia inny, taki, którego dostarczyłyby refleksja nad dziejami ludzkości lub przynajmniej nad XX wiekiem, albo współczesna myśl filozoficzna. Narrator jego biblijnych opowiastek wygłasza morały sugerujące, że istnieje jakaś nadrzędna, wszech- albo przynajmniej wielewiedząca instancja lub też że polemika z Biblią jest prowadzona zgodnie z przyczynowo-skutkowym racjonalnym (lub racjonalistycznym) porządkiem. Morały u Kołakowskiego są parodystyczne, złamane, przewrotne ${ }^{2}$ i choć oferują złudzenie istnienia niepodważalnych racji, w gruncie rzeczy albo kwestionują racje przedstawione w Biblii, albo pod pozorami wiedzy wyrażają bezradność. Najbardziej dotkliwie pokazuje to morał Abrahama czyli Smutku wyższych racji (niedotyczącego wprawdzie porządku historii, a ofiary Izaaka, ale za sprawą podważania czystości boskich intencji podającego w wątpliwość także całe Objawienie):

My [prawdziwi mężczyźni] oceniamy wyniki i wiemy, że wszystko jedno - chciał zabić czy nie chciał zabić - skoro w końcu nie zabił. Dlatego śmiejemy się do rozpuku z fajnego kawału Pana Boga. Ostatecznie sami widzicie, że to morowy chłop (Kołakowski 1990: 123).

Nie ma tu optymizmu wyrastającego z posiadanej wiedzy - o historii - lub mądrości - wyniesionej ze współczesnej filozofii. Co najwyżej pozostaje nam poczucie względności naszych perspektyw i narracji o historii, co Kołakowski wyraża wprost w pierwszych słowach eseju Fabula mundi i nos Kleopatry: „Teza: że w badaniach historyczno-filozoficznych nie istnieje żadna metoda wyjaśniająca" (Kołakowski 1984: 68), zaś kończy swój tekst następującą konstatacją: „Jedyny skromny morał, który stąd wynika, jest ten oto, że trzeba nam stale utrzymywać $\mathrm{w}$ pamięci różnicę między faktem $\mathrm{i} \gg$ fabula $\ll$, która go pochłania [...] Wynika stąd również, że każda »fabula« musi się kończyć tradycyjnym zastrzeżeniem: »quod tamen potest esse aliter«" (ibid.: 72). Można nawet powiedzieć, że nadmiar wiedzy wynikającej z historycznych doświadczeń jeszcze bardziej utrudnia zrozumienie bo do zachwiania historycystycznej koncepcji czasu dochodzi również zawód dotyczący poznawczych możliwości człowieka, szczególnie współczesnego. Zdaje się to dochodzić do głosu w tekście Zygmunta Kubiaka pt. Król Dawid, gdzie poczucie bezradności wobec historii jest wyartykułowane wprost:

2 Więcej na ten temat, podobnie jak i o apokryficzności Opowieści biblijnych L. Kołakowskiego, w: Michalski 2003: 133 in. 
Zamiast gorszyć się klątwami zawartymi w Psalmach, powinniśmy się raczej pochylić nad historią, pochylić się nad Tajemnicą, wobec której takie słowa jak „zgorszenie” tracą sens. Czy jest historia, w której walczą ze sobą ludy i płoną miasta? A nie umiejąc odpowiedzieć na to pytanie, znowu wrócimy do Psalmów i wtedy zrozumiemy, że Dawid woła właśnie z głębi tej nieprzenikliwej gęstwy życia, woła z historii, z dna, z mroku (Kubiak 2002: 231-232).

I tu dochodzimy do kwestii wiedzy, drugiej Gumbrechtowskiej konfiguracji toposów latencji, którą krótko można określić jako „udręki złej wiary i wydobywania prawdy” (Gumbrecht 2015: 207). Apokryficzne prozy biblijne, podobnie jak i inne apokryfy, szczególnie współczesne, mogą wyrastać tyleż z pełnej fascynacji potrzeby uzupełnienia kanonu, co $\mathrm{z}$ hermeneutyki podejrzeń - nie tylko wobec określonego kanonu, ale wobec wszelkiej kanoniczności, a szczególnie metod jej fundowania, gruntowania, utwierdzana i kolportowania. W gruncie rzeczy „wykolejenie historii” - trzecia latentna udręka, którą opisuje Gumbrecht - też wynika z poczucia kompromitacji naszych władz poznawczych, toteż obie te konfiguracje toposów są łączliwe, czyli przeplatanie płaszczyzn czasowych łatwo wiąże się z meandrami wydobywania prawdy zderzającymi się ze złą wiarą. Interesującym tego przykładem jest opowiadanie Gustawa Herlinga-Grudzińskiego pt. Kieł Barabasza, bardzo znamienne zresztą dla apokryficznej poetyki tego pisarza.

Narrator tego tekstu przyjmuje nierzadką u Grudzińskiego rolę i postawę poszukiwacza prawdy, „reportera śledczego”, który w swoich podróżach (i snach - tu jest to ważny wątek) na palimpsestowe, piętrowo układające się tropy prowadzące (pozornie?) dochodzi do wiedzy o - najczęściej - dawnych osobach lub zdarzeniach. Od samej prawdy ważniejsze nieraz okazuje się dochodzenie do niej - droga jest nieraz tak zawiła, że podaje w wątpliwość możliwość ustalenia faktów. Już przedmiot dociekań narratora ma charakter apokryficzny, a przynajmniej (pozornie) drugoplanowy w Biblii - chodzi o Barabasza, za sprawą snu, w którym bohater - alter ego pisarza - uświadamia sobie, że to nie Judasz, ale Bar Abba pełni istotną, choć zapoznaną rolę w historii męczeństwa Chrystusa, a zatem zbawienia, będąc niemal - jak diabeł - cieniem Boga (Herling-Grudziński 2002: 429), zaś z pewnością „aktorem w masce statysty” (ibid.: 418). Być może dlatego, jak zauważa narrator, „musiał poruszać wyobraźnię i rzucać wyzwanie zmysłowi dociekliwości”, jednocześnie „krył się w tej fascynacji zawsze element [...] drugorzędności, przypadkowości, nieokreśloności" (ibid.). To sprawia, że Barabasz niczym Derridiański nierozstrzygalnik pozwala na niemal dowolne dookreślanie, na projekcję różnych wyobrażeń, koncepcji teologicznych czy choćby fabularnych suplementów. A przecież to nie tyle Barabasz jest przedmiotem dociekań, co jego kieł - jak dowiadujemy się na końcu według przytoczonej przez narratora opowieści (apokryficznej!) - wybity mu przez głaz zamykający wejście do grobowca Chrystusa.

Fascynacja tym, co w kanonie marginalne, może być wyrazem typowej dla apokryfów podejrzliwości wobec niego, a jednocześnie potrzebą odkrycia prawdy przez wydobycie na jaw tego, co wydawało się mniej lub bardziej celowo ukryte, zamaskowane, zafałszowane. Ta podejrzliwość wobec oficjalnych, szczególnie wielkich narracji zdaje się korespondować ze Stimmung latencji po 1945 roku. Żeby pokazać bliskość apokryficznego żywiołu z Gumbrechtowskim opisem stanu bycia „pasażerem na gapę”, warto przyjrzeć się, gdzie ukryta jest prawda i jak do niej dociera narrator-bohater Grudzińskiego.

Po pierwsze, powtórzmy, inspiracją dla narratora do podjęcia poszukiwań - najpierw relikwii (tytułowego kła), a potem jej historii w kontekście postaci Barabasza - był sen. Nie 
odbierając marzeniom sennym wartości poznawczych, należy jednak stwierdzić, że w drugiej połowie XX wieku trudno im przyznać istotną epistemologicznie rolę... Można wręcz uznać, że sen stanowi podważenie akceptowalnej, naukowej, racjonalnej drogi prowadzącej do poznania, tym samym można go uznać za wyraz latencji - $\mathrm{i}$ to o tyle silny, że przez ponad dziesięć lat motywował narratora do poszukiwań.

Po drugie mamy tu do czynienia $\mathrm{z}$ wielokrotnymi zapośredniczeniami. Historia kła Barabasza - sama w sobie marginalna, apokryficzna i fantastyczna (i w tym sensie mieszcząca się w spektrum apokryfów ludowych) pochodzi z „klocka Helosa” - pergaminu z IX wieku. Ten zaś zaginął w czasie II wojny światowej, zaś jego zawartość została streszczona przez profesora lokalnej szkoły na początku XX stulecia. I to do jego rękopisu - filologa o znaczącym nazwisku Protocristiani - usiłuje dotrzeć narrator, nie został on bowiem wydrukowany za sprawą zakazu biskupa (mamy zatem element „złej wiary”). Zapiski z początku wieku zostały znalezione u prawnuczki brata profesora, a bohater zapoznaje się $\mathrm{z}$ nimi w pośpiechu w niesprzyjającej aurze, referując czytelnikom to, co zapamiętal. Mamy tu zatem ciąg zapośredniczeń - jednocześnie ujawnionych, a zarazem wcale nie rozjaśniających prawdy (która - przypomnijmy - jest też opisaną po wielu wiekach apokryficzną historią). Narrator zdaje sobie sprawę z problematyczności tej sytuacji: „Siłą rzeczy streszczenie streszczenia zubaża podwójnie i niekiedy gubi po prostu walory oryginału” (Herling-Grudziński 2002: 437).

Po trzecie narrator przedstawia nam wiele wersji i interpretacji postaci Barabasza, zarówno teologicznych, jak i literackich - ze streszczeniem (ponownie!) najbardziej znanej - powieści Pära Lagerkvista. Mnogość narracji i koncepcji nie przybliża do „wyjawienia prawdy" - raczej ją przesłania lub nawet wskazuje, że dotarcie do niej jest niemożliwe (o ile ona w ogóle istnieje...). Paradoksalnie ta wielość może być także wyrazem „złej wiary” o czym będzie mowa zaraz - tu jeszcze warto zaznaczyć, że wspominanie o niej jest elementem budowania wiarygodności przekazu, dość nieoczywistej jednak (do czego wrócę poniżej).

Po czwarte w opowiadaniu pojawiają się istotne elementy „złej wiary”. Powyżej była mowa o nakazie biskupa Vizziniego z Benevento, aby nie publikować historii kła Barabasza. Taką cenzurę można uznać tyleż za wyraz troski o nierozpowszechnianie gorszących (w sensie teologicznym) i fałszywych opowieści, co jednocześnie za przejaw chęci ukrycia prawdy. Dla narratora jednak jeszcze bardziej zagadkowe jest zniknięcie relikwii - w czasie wojny wywieźli ją Niemcy wraz z klockiem Helosa, pozostawiając jednocześnie drogą szkatułę. Pojawia się zatem wprost II wojna światowa - jako zerwanie ciągłości narracji (nieważne: apokryficznych czy kanonicznych), jako wyrwa, przepaść, która nie pozwala dotrzeć do prawdy. I nie tylko: utrudniając jej wyjawienie, sugeruje jednocześnie ważność (?) tego, co - jak Barabasz - pozornie drugorzędne, przypadkowe, nieokreślone. To obciążenie wojną - w tak nieistotnej na pierwszy rzut oka kwestii, dla narratora stanowiącej jednak uwierającego „pasażera na gapę” - wydaje się bezpośrednim tropem latencji.

Po piąte wreszcie narrator buduje swoją wiarygodność na co najmniej trzy sposoby: przywołując wiele wersji i interpretacji historii Barabasza, wyrażając swój krytyczny stosunek lub podejrzliwość oraz wplatając wątki autobiograficzne. O pierwszym była mowa powyżej. Wyrazem drugiego są choćby następujące komentarze: „Naiwnością graniczącą z zamroczeniem umysłu, albo wręcz szaleństwem, musi się czytelnikowi wydawać nadzieja wydarcia jedenastu wiekom skarbca księcia Sicardo z kłem [...]. Ileż już widziałem i prze- 


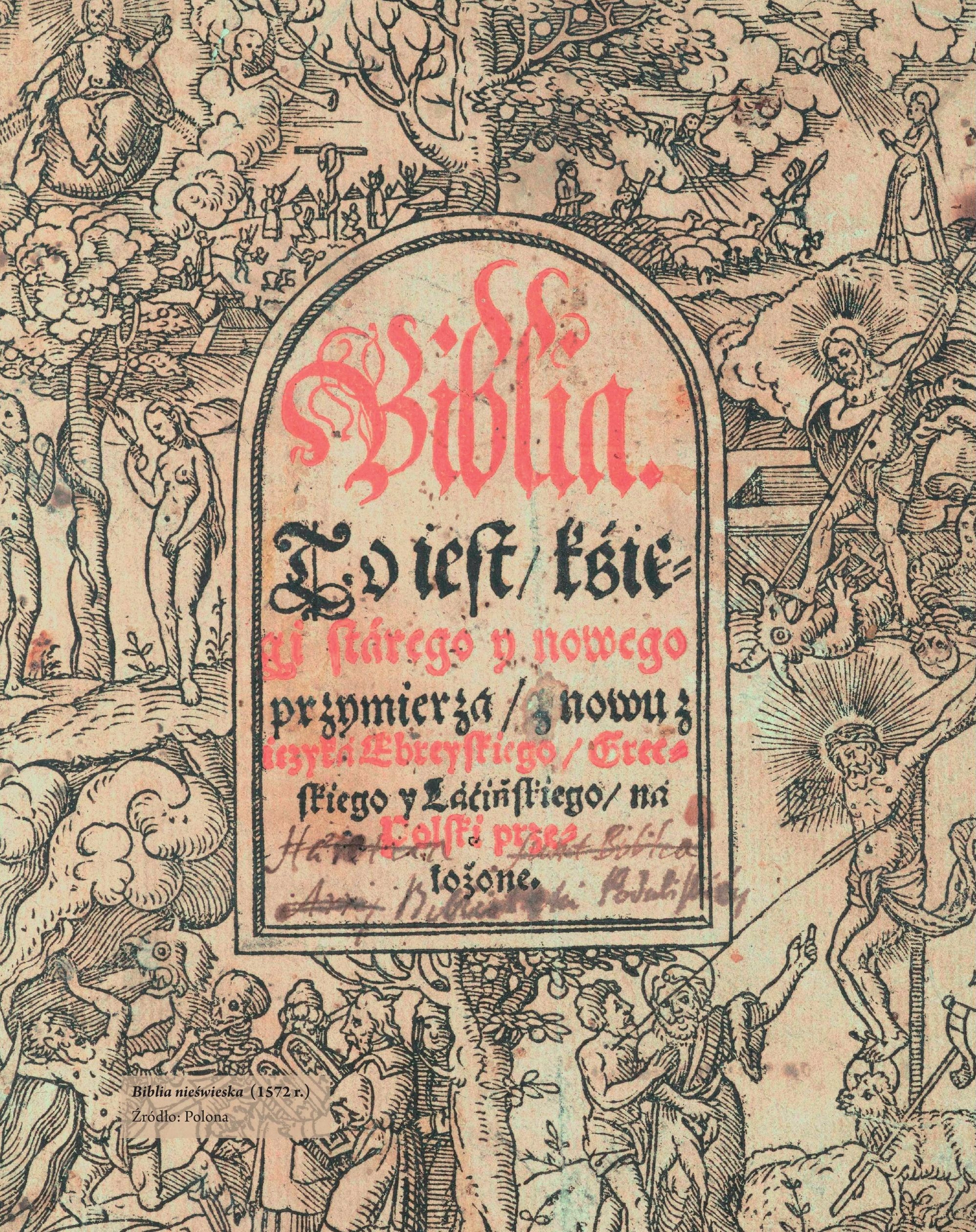


glądałem książek i broszur prowincjonalnych, wydawanych własnym sumptem autorów! Iluż miałem okazję poznać na prowincji »pomyleńców«" (Herling-Grudziński 2002: 424-425). Wreszcie trzeci sposób to typowa strategia uwiarygodniania przez autobiograficzną empiryzację. Warto jednak podkreślić, że wświetle poetyki opowiadań Grudzińskiego (np. casus Błogosławionej świętej, Gasnącego Antychrysta czy przede wszystkim Pragi Kafki) należy zachować sceptycyzm, tym bardziej że swoista „nadwyżka” szczegółów, wersji, danych daje wprawdzie efekt podkreślania wiarygodności (jako „efekt realności”), ale zarazem - w świetle dwudziestowiecznych praktyk literackich (i nie tylko literackich) - rodzi podejrzenie o chęć maskowania, ukrywania prawdy (wracamy zatem do kwestii „złej wiary”). Dzieje się tak m.in. za sprawą wymieszania różnych źródeł o odmiennych statusach i wartości, motywacji i inspiracji bohatera - co może niekoniecznie wyrażać złą wolę, a raczej bezradność poznawczą narratora.

Warto przy okazji dodać, że podobnie jak Grudziński buduje szeroką panoramę zjawiska, odwołując się do różnych tekstów, dyskursów i do doświadczeń (nie tyle własnych, co bohatera), tak i Gumbrecht niezwykle interesująco tka swoją naukową narrację z odwołań do literatury, historii, filozofii, ale także do własnych przeżyć i wspomnień.

Na koniec tej mocno aspektowej i szkicowej interpretacji opowiadania Grudzińskiego warto dodać, że także tu pojawia się wymieszanie perspektyw czasowych - realiów biblijnych i nieco późniejszych, następnie średniowiecznych (z różnych jego okresów), wreszcie dwudziestowiecznych (z początku, czasów II wojny światowej i wreszcie współczesnych pisarzowi). Nie musi to oznaczać wyrazu poczucia „wykolejenia historii”, niemniej trudno oprzeć się wrażeniu, że taka mnogość płaszczyzn czasowych, wymieszanych niesekwencyjnie, wyrasta z przeczucia, że historia, a raczej historyczność nie rządzą już tym światem.

Tym samym w opowiadaniu Gustawa Herlinga-Grudzińskiego, podobnie jak w opowieściach z Klucza niebieskiego Leszka Kołakowskiego, a także - jak można przypuszczać w innych współczesnych apokryfach biblijnych dochodzi do głosu latencja w dwóch co najmniej wyróżnionych przez Hansa Ulricha Gumbrechta konfiguracjach. I nie jest to, jak się wydaje, zamknięty rozdział, bowiem: „To więc, co objawiło się w stanie latencji, stoi u źródła innego porządku czasu - tego, w którym żyjemy teraz" (Gumbrecht 2015: 264).

\section{Bibliografia}

Gumbrecht, Hans Ulrich 2015. Po roku 1945. Latencja jako źródło wspótczesności. Tłum. Aleksandra Paszkowska. Warszawa: Wydawnictwo Krytyki Politycznej.

Herling-Grudziński, Gustaw 2002. „Kieł Barabasza”. W: Małe prozy biblijne. Wybór Maria Jasińska-Wojtkowska, Maciej Nowak, wstęp Maciej Nowak. Lublin: Wydawnictwo KUL.

Kołakowski, Leszek 1984. „Fabula mundi i nos Kleopatry”. W: Leszek Kołakowski. Czy diabeł może być zbawiony i 27 innych kazań. Londyn: Aneks.

— 1990. Bajki różne. Opowieści biblijne. Rozmowy z diabtem, Warszawa: Iskry.

Kubiak, Zygmunt 2002. „Król Dawid”. W: Małe prozy biblijne. Wybór Maria Jasińska-Wojtkowska, Maciej Nowak, wstęp Maciej Nowak. Lublin: Wydawnictwo KUL.

Michalski, Maciej 2003. Dyskurs, apokryf, parabola. Strategie filozofowania w prozie wspótczesnej. Gdańsk: Wydawnictwo Uniwersytetu Gdańskiego. 
Nowak, Maciej 2002. „Inspiracje biblijne w małych formach prozatorskich”. W: Małe prozy biblijne. Wybór Maria Jasińska-Wojtkowska, Maciej Nowak, wstęp Maciej Nowak. Lublin: Wydawnictwo KUL. 5-45.

Pilinszky, János 1999. Apokryf. Tłum. Jerzy Snopek. Sejny: „Pogranicze”.

Szajnert, Danuta 2000. „Mutacje apokryfu”. W: Włodzimierz Bolecki, Ireneusz Opacki (red.). Genologia dzisiaj. Warszawa: Wydawnictwo IBL PAN. 137-159. 